\title{
D-Dimer Level with Cerebral Venous Sinus Thrombosis (CVST) Occurrence Using Digital Subtraction Angiography (DSA)
}

\author{
Afdi Arahim Putra, ${ }^{1}$ Eppy Buchori, ${ }^{2}$ Hilman, ${ }^{2}$ Lisda Amalia ${ }^{3}$ \\ ${ }^{1}$ Radiology Study Program, Faculty of Medicine, Universitas Padjadjaran/Dr. Hasan Sadikin General Hospital, \\ Bandung, Indonesia, ${ }^{2}$ Department of Radiology, Faculty of Medicine, Universitas Padjadjaran/Dr. Hasan \\ Sadikin General Hospital, Bandung, Indonesia, ${ }^{3}$ Department of Neurology, Faculty of Medicine, \\ Universitas Padjadjaran/Dr. Hasan Sadikin General Hospital, Bandung, Indonesia
}

\begin{abstract}
Cerebral venous sinus thrombosis (CVST) is a cerebrovascular disease in the form of occlusion due to thrombus in the venous and cerebral sinuses. It rarely occurs and has varied clinical symptoms and radiological features and challenging to diagnose. D-dimer used as a diagnostic marker for cases of venous thromboembolism, with a sensitivity of around $90-92 \%$. However, the specificity is not too high (70-73\%) because it can also increase in other conditions. Digital subtraction angiography (DSA) is a gold standard examination to establish the diagnosis of CVST. The purpose of this study was to determine the relationship between the D-dimer level and CVST using DSA at Dr. Hasan Sadikin General Hospital in Bandung. This study used an observational analytic method with a case-control study design using retrospective data from medical records at Dr. Hasan Sadikin General Hospital in January 2017-August 2019. The research subjects divided into two groups, namely the high D-dimer levels and the normal/low D-dimer level. Forty people meet the inclusion criteria, ages averaging from $44.77 \pm 14.40$ years, and consists of 9 male patients (22\%) and 31 women patients (78\%). For normal/low D-dimer levels 20 patients (50\%) and high D-dimer levels 20 patients (50\%). Statistical test results measuring D-dimer and CVST levels found a significant relationship ( $\mathrm{p}<0.05)$. In conclusion, there is a relationship between D-dimer levels with CVST events that have been done by DSA. The higher the D-dimer level, the higher the suspicion of CVST.
\end{abstract}

Key words: CVST, D-dimer, DSA

\section{Kadar D-Dimer dengan Kejadian Cerebral Venous Sinus Thrombosis (CVST) Menggunakan Digital Subtraction Angiography (DSA)}

\begin{abstract}
Abstrak
Penyakit cerebral venous sinus thrombosis (CVST) merupakan penyakit serebrovaskular berupa oklusi akibat trombus di saluran vena dan sinus serebral yang jarang terjadi dengan gejala klinis dan gambaran radiologis yang bervariasi, serta sangat sulit untuk didiagnosis. D-dimer dapat dijadikan sebagai penanda diagnostik bagi kasuskasus tromboembolisme vena dengan sensitivitas 90-92\%, namun spesifisitasnya tidak terlalu tinggi $(70-73 \%)$ karena dapat juga meningkat pada kondisi lain. Digital subtraction angiography (DSA) merupakan pemeriksaan baku emas untuk menegakkan diagnosis CVST. Tujuan penelitian ini mengetahui hubungan antara kadar D-dimer dan CVST menggunakan DSA di RSUP Dr. Hasan Sadikin Bandung. Penelitian ini merupakan observasional analitik dengan rancangan kasus kontrol menggunakan data retrospektif dari rekam medis di RSUP Dr. Hasan Sadikin Bandung pada bulan Januari 2017-Agustus 2019. Subjek penelitian dibagi menjadi 2 kelompok, yaitu kelompok D-dimer tinggi dan kelompok D-dimer normal/rendah. Hasil penelitian didapat 40 orang yang memenuhi kriteria inklusi, usia rerata $44,77 \pm 14,40$ tahun yang terdiri atas pasien laki-laki 9 orang (22\%) dan perempuan 31 orang (78\%). Untuk kadar D-dimer kategori normal/rendah 20 orang (50\%) dan tinggi 20 orang (50\%). Hasil uji statistik mengukur kadar D-dimer dan CVST didapatkan hubungan yang bermakna $(\mathrm{p}<0,05)$. Simpulan, terdapat hubungan antara kadar D-dimer dan kejadian CVST yang telah dilakukan DSA. Semakin tinggi kadar D-dimer, semakin tinggi kecurigaan kejadian CVST.
\end{abstract}

Kata kunci: CVST, D-dimer, DSA

Received: 12 November 2019; Revised: 17 December 2019; Accepted: 28 December 2019; Published: 31 December 2019 Correspondence: Afdi Arahim Putra. Department of Radiology, Faculty of Medicine, Universitas Padjadjaran/Dr. Hasan Sadikin General Hospital. Jln. Pasteur No. 38, Bandung 40161, West Java, Indonesia. E-mail: putra.afdi@gmail.com 


\section{Introduction}

Cerebral venous sinus thrombosis (CVST) is a rare cerebrovascular disease in the form of occlusion due to thrombus in the venous canal and cerebral sinuses. It has different clinical and radiological features that make it very difficult to diagnose. Underdiagnoses of CVST can cause severe complications, including infarction, and bleeding to death. ${ }^{1}$

Cerebral veins contain about $70 \%$ of the total brain blood volume. CVST occurs about a thousand times less than arterial strokes. Arterial and venous strokes cause different neurological deficits and affect all age groups. About half of arterial stroke patients are found at people of 75 years of age or older, while CVST is most common in people less than 40 years of age (young adults and children). It estimated that the incidence of CVST is around two to seven cases per one million people each year; three out of four people with CVST are women, with $61 \%$ of women aged between 20-35 years. This comparison may be related to pregnancy or the use of oral contraceptives. One in eight patients will die or ended up with disability. ${ }^{2}$

What distinguishes veins in the brain from other veins in the body is that veins in the brain do not have valves, allowing infection of the area around the veins and sinuses to spread in both directions, the venous system in the brain has many collaterals so that occlusion can arise without symptoms. ${ }^{3,4}$

Headache is the most common symptom of CVST. The symptom can be the only clinical manifestation or can be associated with other signs or symptoms of CVST. When symptoms of headache found, CVST is most often associated with lateral sinus thrombosis. ${ }^{3}$

Several studies have shown poor clinical results in about $10 \%$ of all CVST cases. A study reported that an initial diagnosis of CVST errors could occur in $73 \%$ of patients. Besides, delays in diagnosis for more than ten days can also occur in $40 \%$ of patients who hospitalized. ${ }^{1}$

In developing countries where most cases with CVST occur, biological markers accessible to performed and affordable are needed. D-dimer is a marker of endogenous fibrinolysis and must therefore be detected in patients with deep vein thrombosis. D-dimer levels in plasma which are cross-linked fibrin fragments that are degraded by plasmin are sensitive for the diagnosis of deep venous thrombosis and pulmonary thromboembolism. ${ }^{5}$

D-dimer recommended as an adjunct test. Since d-dimer is a sensitive test but has a poor specificity $(70-73 \%)$, it should only use to rule out deep vein thrombosis (DVT), not to confirm a diagnosis. High plasma D-dimer level >2.0 $\mathrm{mg} / \mathrm{mL}$ found in $68 \%$ of patients with DVT and $45 \%$ without DVT $(\mathrm{p}<0.05)$. Therefore, a high D-dimer level greater than $2.0 \mathrm{mg} / \mathrm{mL}$ showed $68 \%$ sensitivity, $55 \%$ specificity, $60 \%$ accuracy, $50 \%$ positive predictive rate, and $72 \%$ negative predictive rate in the detection of early DVT. However, it should also be noted that D-dimer levels could increase in certain pathological conditions besides thromboses such as cancer, liver disease, kidney disease, organ-graft repair, and thrombolysis treatment. Therefore, to increase the effectiveness of detecting thrombosis, a combination of $\mathrm{D}$-dimer is required with a fibrinogen test. ${ }^{6}$

Although an increase in D-dimer has been shown to be associated with CVST, its predictive value in diagnosing CVST has not been clinically established. The aim of this study is to re-evaluate the D-dimer plasma value in CVST predictions with a greater number of cases from patients that are grouped according to acute CVST or suspect of CVST and their corresponding controls. ${ }^{7}$

Currently there are many radiological modalities that can be used to help with the diagnosis of CVST, ranging from computed tomography scan (CT-scan), magnetic resonance imaging (MRI), CT venography, MR venography to digital subtraction angiography (DSA) which clearly show veins in the brain and changes in brain parenchyma associated with thrombosis. ${ }^{8}$

Angiographic or DSA features in CVST patients will lack complete or partial filling. However, it is sometimes difficult to capture in certain areas such as one third anterior of the superior sagittal sinus or the lateral sinus. In the indirect sign, there is delayed emptying and dilation. Collateral veins (cortical, emissary, meningeal, diploic, and scalp veins) accompanied by the corkscrew appearance phenomenon. ${ }^{9-11}$

Digital subtraction angiography (DSA) is a minimally invasive diagnostic technique used to clearly depict arteries and veins. ${ }^{2,12,13}$ DSA is still considered a gold standard test. When there is clinical suspicion in CVST patients, but the MRV or CTV examination shows no abnormalities, therefore DSA is the first choice. ${ }^{14}$ The purpose 
of this study was to determine the relationship between the D-dimer level and CVST using DSA at Dr. Hasan Sadikin General Hospital in Bandung.

\section{Methods}

This study was an analytic observational with a case-control design using retrospective data from medical records at Dr. Hasan Sadikin General Hospital Bandung from January 2017 to August 2019. The research subjects divided into two groups, the high D-dimer level group and the normal/low D-dimer level group with a total sample of 40 people who met the inclusion criteria.

Numerical-scale data such as patient age presented with the mean, standard, deviation, median, and range. For characteristics data in the form of categorical data such as the gender of the patient, code is given and presented as frequency and percentage distributions. Before statistical tests, the numerical data assessed by normality tests using the Shapiro-Wilk test. The significance test in this study uses the unpaired $t$ test, while for statistical analysis for categorical data, it tested with the chi-square requirements.

The significance criteria used are the value of $p$, if $\mathrm{p} \leq 0.05$ is significant or statistically significant, while $p>0.05$ is insignificant or not statistically significant. The data obtained are recorded in a unique form and then processed through the SPSS version 24.0 for Windows.

This study conducted after obtaining the feasibility permit from the Health Research Ethics Committee of Dr. Hasan Sadikin General Hospital Bandung with letter number: LB.02.01/X.6.5/249/2019.

\section{Results}

Table 1 describes the characteristics of the study subjects based on age, gender, and D-dimer level. Age average is $44.77 \pm 14.40$ years, and there is more female than male ( $78 \%: 22 \%)$.

Table 2 explains the description of the results of DSA on the most research subjects is the left transverse sinus, 22 people (55\%). To see the relationship between D-dimer levels with CVST events using DSA can be seen in Table 3 .

In the DSA results group (+), the study subjects with normal or low D-dimer levels were eight people (30\%) and subject with high 19 people (70\%). In the DSA results group (-), research subjects with normal or low levels D-dimer are 12
Table 1 Characteristics of Research Subjects

\begin{tabular}{lc}
\hline Variables & $\mathbf{n = 4 0}$ \\
\hline Age & \\
Mean \pm Std & $44.77 \pm 14.40$ \\
Median & 45.00 \\
Range (min-max) & $20.00-80.00$ \\
Gender & \\
Male & $9(22 \%)$ \\
Female & $31(78 \%)$ \\
D-dimer level & \\
Normal/low & $20(50 \%)$ \\
High & $20(50 \%)$ \\
\hline
\end{tabular}

people (12 of 13), and subject with a high level is one person (1 of 13).

For the analysis of categorical data, the D-dimer level tested using the chi-square test. The value of $\mathrm{p}$ on the $\mathrm{D}$-dimer content variable is less than 0.05 ( $\mathrm{p}$ value<0.05), which means there is a statistically significant difference between the variable of D-dimer in the DSA (+) and (-) results groups.

\section{Discussion}

In this study, it inferred that the CVST incidence is higher in females, with 31 of 40 . The result is consistent with the literature, which states that the highest incidence of CVST is in women with a ratio of 3:1 and in the age groups of 40 years or younger. The prevalence of CVST is common in women, perhaps due to conditions related to pregnancy, the puerperium and the use of oral contraceptives. $^{2}$

The highest number of occlusions in DSA in the left transverse sinus was 55\%. The results are not following the study of Galarza and Gazzeri, ${ }^{15}$ who concluded CVST more often happened in the superior sagittal sinus, which is $62 \%$.

Table 2 Overview of DSA Results

\begin{tabular}{lc}
\hline DSA Result & $\mathbf{n = 4 0}$ \\
\hline Right transverse sinus & $4(10 \%)$ \\
Left transverse sinus & $22(55 \%)$ \\
Bilateral transverse sinus & $1(2 \%)$ \\
Superior sagitalis sinus & $\mathrm{O}(0 \%)$ \\
Normal & $13(33 \%)$ \\
\hline
\end{tabular}


Table 3 Comparison between D-dimer Levels and CVST Occurrence Using DSA

\begin{tabular}{lccc}
\hline \multirow{2}{*}{ D-dimer Level } & \multicolumn{2}{c}{ DSA Result Group } & \multirow{2}{*}{$\mathbf{p}$ Value } \\
\cline { 2 - 3 } & $\mathbf{( + )} \mathbf{n}=\mathbf{2 7}$ & $\mathbf{( - )} \mathbf{n = 1 3}$ & \\
\hline Normal/low & 8 & 12 & 0.0001 \\
High & 19 & 1 & \\
\hline
\end{tabular}

Thrombosis in the superior sagittal sinus will cause an increase in venous pressure, resulting in impaired cerebrospinal fluid absorption which will cause an increase in intracranial pressure with clinical signs and symptoms like headache, focal neurological deficits, seizures and decreased consciousness. ${ }^{14,16,17}$

There is a significant relationship between D-dimer levels with CVST events using DSA. CVST is common in the high D-dimer level group, which is 19 of 27 . The study is consistent with research conducted by Wang et al., ${ }^{8}$ who found a significant relationship between high D-dimer levels and the incidence of CVST. D-dimers can also be used as diagnostic markers for cases like venous thrombosis, prediction of prognosis, as well as clinical monitoring and therapy in CVST. ${ }^{18,19}$

This research is retrospective so that it is investigated for the causes of prothrombotic and risk factors and does not assess the effect of D-dimer levels on clinical symptoms and clinical features.

\section{Conclusion}

Cerebral venous sinus thrombosis (CVST) is a rare cerebrovascular disease that varies in clinical symptoms and radiological features and very difficult to diagnose. DSA is a diagnostic examination of choice when there is clinical suspicion of CVST patients.

\section{Conflict of Interest}

The author has reported that no potential conflicts of interest exist with any companies/ organizations whose products or services may be discussed in this article.

\section{References}

1. Tatlisumak T, Jood K, Putaala J. Cerebral venous thrombosis: epidemiology in change. Stroke. 2016;47(9):2169-70.
2. Leach JL, Fortuna RB, Jones BV, GaskillShipley MF. Imaging of cerebral venous thrombosis: current techniques, spectrum of findings, and diagnostic pitfalls. Radiographics. 2006;26(Suppl 1):S19-41.

3. Atanassova PA, Massaldjieva RI, Chalakova NT, Dimitrov BD. Cerebral venous sinus thrombosis-diagnostic strategies and prognostic models: a review. In: Okuyan E, editor. Venous thrombosis: principles and practice [e-book]. Rijeka, Croatia: InTech; 2012 [cited 28 August 2019]:129-58. Available from: https://www.intechopen. com/books/venous-thrombosis-principlesand-practice/cerebral-venous-sinusthrombosis-diagnostic-strategies-andprognostic-models-a-review.

4. Uflacker R. Atlas of vascular anatomy: an angiographic approach. $2^{\text {nd }}$ Edition. Philadelphia: Lippincott Williams \& Wilkins; 2007.

5. Crassard I, Soria C, Tzourio C, Woimant F, Drouet L, Ducros A, et al. A negative D-dimer assay does not rule out cerebral venous thrombosis: a series of seventy-three patients. Stroke. 2005;36(8):1716-9.

6. Raskob GE, Angchaisuksiri P, Blanco AN, Buller H, Gallus A, Hunt BJ, et al. Thrombosis: a major contributor to global disease burden. Arterioscler Thromb Vasc Biol. 2014;34(11):2363-71.

7. Chapin JC, Hajjar KA. Fibrinolysis and the control of blood coagulation. Blood Rev. 2015;29(1):17-24.

8. Wang HF, Pu CQ, Yin X, Tian CL, Chen T, Guo JH, et al. D-dimers (DD) in CVST. Int J Neurosci. 2017;127(6):524-30.

9. Saadatnia M, Fatehi F, Basiri K, Mousavi SA, Mehr GK. Cerebral venous sinus thrombosis risk factors. Int J Stroke. 2009;4(2):111-23.

10. Wasay M, Azeemuddin M. Neuroimaging of cerebral venous thrombosis. J Neuroimaging. 2005;15(2):118-28.

11. Sasidharan PK. Cerebral vein thrombosis misdiagnosed and mismanaged. Thrombosis. 
2012;2012:210676.

12. Qu H, Yang M. Early imaging characteristics of 62 cases of cerebral venous sinus thrombosis. Exp Ther Med. 2013;5(1):233-6.

13. Zhang S, Hu Y, Li Z, Huang D, Zhang M, Wang $\mathrm{C}$, et al. Endovascular treatment for hemorrhagic cerebral venous sinus thrombosis: experience with 9 cases for 3 years. Am J Transl Res. 2018 Jun 15;10(6):1611-9.

14. Piazza G. Cerebral venous thrombosis. Circulation. 2012;125(13):1704-9.

15. Galarza M, Gazzeri R. Cerebral venous sinus thrombosis associated with oral contraceptives: the case for neurosurgery. Neurosurg Focus. 2009;27(5):E5.
16. Saposnik G, Barinagarrementeria F, Brown RD Jr, Bushnell CD, Cucchiara B, Cushman $\mathrm{M}$, et al. Diagnosis and management of cerebral venous thrombosis: a statement for healthcare professionals from the American Heart Association/American Stroke Association. Stroke. 2011;42(4):1158-92.

17. Stam J. Thrombosis of the cerebral veins and sinuses. N Engl J Med. 2005;352(17):1791-8.

18. Lip GY, Lowe GD. Fibrin D-dimer: a useful clinical marker of thrombogenesis? Clin Sci (Lond). 1995;89(3):205-14.

19. Wang J, Ning R, Wang Y. Plasma D-dimer level, the promising prognostic biomarker for the acute cerebral infarction patients. $J$ Stroke Cerebrovasc Dis. 2016;25(8):2011-5. 